Original article

\title{
In vivo study of the antidiabetic activity of aqueous and acetonic extracts of Drimia maritima $\mathbf{L}$.
}

\author{
Yamina Bouatrous \\ Laboratory of Genetics, Biotechnology and Valorization of Bio-Resource (GBVB), Department of Natural Sciences \\ and Life, Faculty of Exact Sciences and Natural Sciences and Life, Mohamed Khider University, Biskra, Algeria
}

Received October 24, 2019: Revised December 15, 2019: Accepted December 17, 2019: Published online December 30, 2019

\begin{abstract}
Diabetes is a metabolic syndrome characterized by chronic hyperglycemia due to a lack of insulin secretion, insulin action (sensitivity), or a combination of both. Postprandial hyperglycemia is highly dependent on the amount of monosaccharides absorbed and their rate of absorption in the small intestine. One of the therapeutic approaches to the treatment of diabetes is the inhibition of digestive enzymes ( $\alpha$ amylase and $\alpha$ glucosidases). Our work is based on the evaluation of the antidiabetic activity of a medicinal plant, Drimia maritime L. They are investigated for their antidiabetic effect in vivo in mice subjected to postprandial hyperglycemia induced by starch or glucose. To this end, aqueous (decoction) and acetone extracts of different organs of two varieties of $D$. maritima have been prepared according to traditional use; have been subjected to phytochemical analysis to highlight different families of chemical compounds such as phenolic compounds including flavonoids, tannins and anthocyans.

Among our results, we found that the content of different chemical compounds differs from one variety to another, and within the same variety from one organ to another. In comparison to the polyphenol content in the leaves and bulbs, it has been found that the content, in the leaves is higher than in the bulbs, so the red variety shows the high polyphenol content of $283 \mu \mathrm{g}$. Eq AG/mg, compared to the white variety $152 \mu \mathrm{g}$. Eq $\mathrm{AG} / \mathrm{mg}$ and flavonoids $98.68 \mu \mathrm{g}$. Eq catechin $/ \mathrm{mg}$ extract on the other hand, the white variety $43.2 \mu \mathrm{g}$. Eq catechin/mg, The polyphenols measured in the different extracts, are mainly flavonoids and more concentrated for the acetone extract. Concerning anthocyanins, they are only found in the red variety.

The results of antidiabetic activity show a positive correlation between polyphenols, flavonoids and anthocyanins and the behavior of diabetic mice. They are, therefore, responsible for this activity. Also, remains the use of acetone extracts of the red variety to treat diabetic mice, shows a greater effect than after 21 days reaches the value of $1.8 \mathrm{~g} / 1$, compared to the white variety, this phenomenon can explain by the different chemical composition between the two varieties of rill. These results confirm the traditional use of this plant as an antidiabetic, and highlight one of their possible mechanisms of action, the reduction of postprandial hyperglycemia by slowing intestinal glucose absorption.
\end{abstract}

Key words: Drimia maritima L., antidiabetic activity, flavonoid, tanins, anthocyan

\section{Introduction}

The Scill is a Mediterranean plant, perennial by a huge bulb whose diameter reaches, in Algeria, 20 to $30 \mathrm{~cm}$ and its weight, 5 to $7 \mathrm{~kg}$. It is made up of nested scales, also known as tunics or flakes, of a whitish colour called Italian Scill or "female" Scill or reddish Scill from Spain or "male" Scill, depending on the variety. The outer scales are plain and membranous, the medium scales are thick and fleshy (Hammiche et al., 2013). The flowered stem (about $1 \mathrm{~m}$ ) has

Author for correspondence: Dr. Yamina Boutrous

Assistant Professor, Laboratory of Genetics, Biotechnology and Valorization of Bio-Resource (GBVB), Department of Natural Sciences and Life, Faculty of Exact Sciences and Natural Sciences and Life, Mohamed Khider University, Biskra Algeria, BP145 RP, 07000-Algeria E-mail: y.bouatrous@univ-biskra.dz

Tel.: +21333724498

Copyright (C) 2019 Ukaaz Publications. All rights reserved.

Email: ukaaz@yahoo.com; Website: www.ukaazpublications.com a bunch of small white flowers with a star-shaped corolla at its end (Joly et al., 2010)

Only the bulb of the Scill contains the main components which are cardiotonic heteroglycosides: scillarenes A and B, scillipicrine, scillin, scillitoxin.

Scillarene A and scillarene B are two steroid cardiotonic heteroglycosides, of the bufadienolide type.

The red Scille has a particular heteroside, the scilliroside (C32 H44 O12), Scilliroside Proscillaridin A, Scilliglaucoside, Scillicyanoside. (E1 Fennouni, 2012).

The use of plants for therapeutic purposes is reported in ancient Arabic, Chinese, Egyptian, Hindu, Greek, Roman and Greek literature. Our ancestors (Wojdylo et al., 2007) knew the therapeutic power of plants empirically Thus, we knew nothing about the 
chemical composition of the remedies used every day by many populations for healthcare.

Since 1980, scientists from all over the world have focused largely on the research of new therapeutic molecules of natural origin. This trend can be largely explained by the urgent need for new treatments, for several reasons, including the increase in the side effects of sometimes serious synthetic drugs (Schlienger, 2014).

Diabetes is a complex and serious chronic disease that is progressing very significantly across all regions of the world. The number of people with diabetes has increased dramatically in recent years (Debussche and Balcou-Debussche, 2018). In some parts of the world, before the advent of insulin injections and other pharmaceutical preparations, healers often used agro-medicinal and food resources considered and proven to be antidiabetic. D. maritima is a bulbous plant of the family Liliaceae according to the classical classification, or Asparagaceae or Hyacinthaceae according to the phylogenetic classification. Arabic vernacular names: Ansal, Bçal al far, Achkil, Faraoun; English: Squill, Red squill; French: Great onion, Sea onion, Maritime onion, Scilla, Scilla, Shrimp, Shrimp; Spanish: Escila

The therapeutic use of this plant is poorly known, for the reason this species has been chosen for phytochemical and antidiabetic studies.

\section{Materials and Methods}

\subsection{Phytochemical study of Drimia maritima L.}

\subsubsection{Plant material}

Both varieties of D. maritima were harvested in the Constantine region in spring.

Voucher specimen are deposited in the herbium of the Department of Nature and Life Sciences, University of Biskra, Algeria under the code LIL-022-6-2018 after drying in room temperature only leaves and the bulb. The aerial part of the plant was dried in the laboratory in the shade, and was ground into fine powder using an electric grinder and carefully stored until it was used. On the other hand, the underground part (the bulb) to preserve them and facilitate drying in the sun or in the oven, the scales is cut into transverse strips.

\subsection{Phenolic compounds}

\subsubsection{Acetone extract}

The extraction of total phenolic compounds is a solid-liquid extraction the principle consists in dissolving the active principle inside the solid and dragging it out using a solvent. Most authors suggest that solvent entry is through an osmotic mechanism and the release of the solute by dialysis or diffusion (Ribereau-Gayon $1971)$; acetone-water $(70 / 30 \mathrm{~V} / \mathrm{V})$ was using as solvent respectively.

\subsubsection{Aqueous extract}

Preparation of aqueous extracts according to the method, an aqueous maceration was also carried out on $100 \mathrm{~g}$ of powder with $1000 \mathrm{ml}$ of distilled water and placed under agitation for $24 \mathrm{~h}$, after filtration the extract was lyophilized.

\subsection{Mode of operation}

Determination of polyphenols by the Folin and Ciocalteu method.

A calibration curve at different gallic acid concentrations was prepared $(0-250 \mathrm{~g} / \mathrm{ml})$ (Figure 1).

\subsubsection{Determination of flavonoids}

\section{Principle}

The quantification of flavonoids in the extract was performed by an aluminum trichloride $\left(\mathrm{AlCl}_{3}\right)$ colorimetric method adapted by (Mounia, n.d.).

In the presence of $\mathrm{AlCl}_{3}$, flavonoids, absorbance at $430 \mathrm{~nm}$, concentration $(\mathrm{g} / \mathrm{ml})$. dihydroxylated on rings $\mathrm{A}$ or $\mathrm{B}$ and free hydroxyl groups in position $\mathrm{C}-3$ and $\mathrm{C}-5$ or ketone group in position C-4, are capable of forming a stable yellowish acid complex absorbed in the visible at $430 \mathrm{~nm}$.

\section{Mode of operation}

$1 \mathrm{ml}$ of each extract is added $1 \mathrm{ml}$ of $2 \%$ aluminium chloride solution $\left(\mathrm{AlCl}_{3}\right)$ in each solvent (ethanol and distilled water). A witness is prepared under the same conditions. Ten minutes after the start of the reaction, the absorbance is read at $430 \mathrm{~nm}$.

A standard range is established separately with quercitine (0-40ug/ $\mathrm{ml}$ ) to calculate the concentration of flavonoids in each extract (Figure 2).

\subsubsection{Anthocyanin extraction}

According to the protocol described by Eryilmaz (Eryilmaz, 2006), the leaves are homogenized in $3 \mathrm{ml}$ of methanol- $\mathrm{HCl}(1 \% \mathrm{HCl})$. The samples were left at $4{ }^{\circ} \mathrm{C}$ in the refrigerator for $48 \mathrm{~h}$. The extract is filtered and used as a source of anthocyanins. The content of anthocyanins has been measured, the extracts have been filtered and the total content of anthocyanins has been measured using a visible UV spectrophotometer, representing the difference between the absorbance at 530 and $657 \mathrm{~nm}$ wavelength and placed in formula A530-A657 to eliminate the chlorophyll content in the extract, quantitatively defined by DO $530 \mathrm{~g}-1$ fresh weight.

\subsection{Study of the antidiabetic activity of D. maritima}

The animals used in this study of antidiabetic activity are 'Wistar' strain mice, aged 2 to 3 months, with a body weight (bw) between 60 and $85 \mathrm{~g}$. The animals were raised in the animal house of the Biology Department, Faculty of Natural and Life Sciences, Mohamed Khider Biskra University. All the procedure performed on animals were approved and conducted in accordance with the National Institute of Health Guide (Reg. No. 488/160/1999/CPCSEA).

All animals are treated and handled according to the standards dictated in the manuals on the care and use of experimental animals (Rowsell, 1986; Festing and Maletzky, 2011). Commercial food and tap water are proved to the animal.

The food used in our experiments is market under the name of El $\mathrm{ALF}$, and has the following nutrient composition: $14 \%$ moisture, $49.5 \%$ carbohydrates, $14 \%$ crude protein, $3.5 \%$ fat, $5 \%$ ash and $1 \%$ mineral-vitamin complex. 
We have used 200 mice which were divided between normal mice (non-diabetic) (50 mice) and mice made diabetic by alloxan (experimental diabetes) (150 mice), and we used three procedures: short-term test, oral glucose tolerance test and long-term test.

\subsubsection{Induction of experimental diabetes}

Fasting mice $(16 \mathrm{~h})$ were treated with a single intraperitoneal dose of alloxan at $60 \mathrm{mg} / \mathrm{kg}$ b.w, prepared just prior to injection in citrate buffer $(0.01 \mathrm{M}, \mathrm{pH} 4.5)$. After $72 \mathrm{~h}$ of alloxan injection, mice with blood glucose levels greater than or equal to $300 \mathrm{mg} / \mathrm{dl}$ are considered diabetic and are used in experiments.

\subsubsection{Study of the antidiabetic activity of aqueous extract (EA) in normal and diabetic rats}

In order to evaluate the antidiabetic activity of the aqueous (EA) and acetone extract of D. maritima in laboratory mice, three procedures were used: short-term study, oral glucose tolerance test and long-term study.

\subsubsection{Short-term study}

20 normal fasting mice were divided into four groups $(\mathrm{n}=5)$, and were treated orally with EA extract at doses of $0.2,0.4,0.6$, and 0.8 $\mathrm{mg} / \mathrm{kg}$ bw. Blood glucose levels were measured at $0 \mathrm{~min}$ (before feeding), $60,120,180,180,240$ and $360 \mathrm{~min}$ on a drop of blood collected from the caudal end of the animals. A glucose meter (vital check), 5 mice were used as a control group and were force-fed with saline solution $(0.9 \% \mathrm{NaCl}, 10 \mathrm{ml} / \mathrm{kg} \mathrm{bw})$. Another batch of 20 mice was used for the acetone extract and follows the same procedure as the aqueous extract.

\subsubsection{Oral glucose tolerance test}

15 normal fasting mice were divided into three groups $(n=5)$, and were treated orally with EA extract at 0.2 and $0.8 \mathrm{mg} / \mathrm{kg}$ bw, $60 \mathrm{~min}$ before glucose solution ( $2 \mathrm{~g} / \mathrm{kg} \mathrm{bw}$ ) was administered. Blood glucose levels, were measured at $0 \mathrm{~min}$ (before aqueous extract gavage), 60 min (before glucose gavage), 90, 120.150, and $180 \mathrm{~min} .5$ mice were used as controls and were gave with $\mathrm{NaCl}$ solution $(0.9 \% 10 \mathrm{ml} / \mathrm{kg}$ bw). In each group, blood glucose levels were measured on a drop of blood collected from the caudal end of the animals, using the glucose meter.

\subsubsection{Long-term study (7 days)}

15 diabetic mice were divided into three groups $(n=5)$. The aqueous extract (EA) was administered orally at a dose of 0.2 and $0.4 \mathrm{mg} / \mathrm{kg}$ bw per day for 7 days to one (experimental) group, the other group being the control group, and was treated in parallel with saline ( $\mathrm{NaCl} 0.9 \%, 10 \mathrm{ml} / \mathrm{kg} \mathrm{bw}$ )

In both groups, fasting blood glucose levels in mice were measured on a drop of blood collected from the caudal end on day 1 and day 7. The same procedure was carried out for the acetone extract.

\section{Results}

The content of the different secondary metabolites (polyphenols, flavonoids) was calculated from the calibration sections shown in Figures 1, 2.

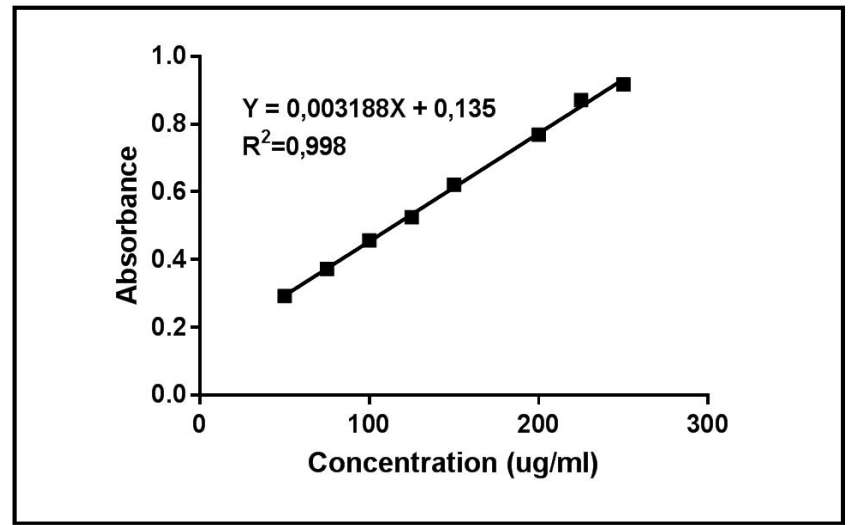

Figure 1: Calibration curve for gallic acid.

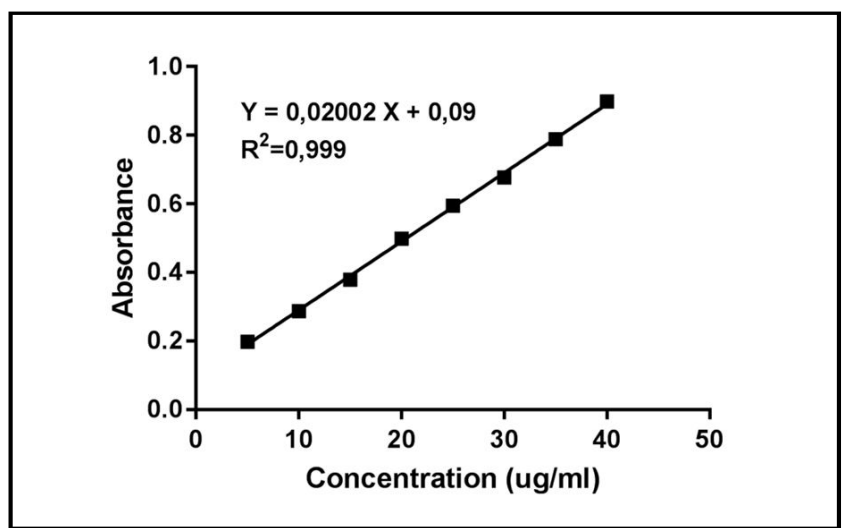

Figure 2: quercitin calibration curve.

\subsection{Phytochemical study}

According to the two-factor analysis of variance at $p>0.05$ processed by MINITAB 13 (Table 1), a signed difference was found between the two of $D$. maritima regardless of the organ tested (Figure 3), with the highest content represented by the red variety (98 and $283 \mathrm{mg} \mathrm{EG/g} \mathrm{MS)} \mathrm{for} \mathrm{the} \mathrm{leaf} \mathrm{and} \mathrm{bulb,} \mathrm{respectively.} \mathrm{The}$ white variety was characterized by a low content (68 and $152 \mathrm{mg}$ EG/MS).

Table 1: ANOVA with two controlled factors: polyphenols (POLY) according to variety (VAR); EXTRACT

\begin{tabular}{|l|l|l|l|l|l|}
\hline \multicolumn{7}{|c|}{ Analysis of variance for polyphenols } \\
\hline Source & DL & SC & CM & F & $p$ \\
\hline VAR & 3 & 80535 & 26845 & 28.13 & 0.011 \\
EXTRACT & 1 & 3785 & 3785 & 3.97 & 0.0140 \\
Erreur & 3 & 2863 & 954 & & \\
\hline Total & 7 & 87182 & & & \\
\hline
\end{tabular}

The same observation for flavonoids, the red variety richer in flavonoids compared to the white variety with a content of (28 and $43 \mathrm{mg} \mathrm{EQ} / \mathrm{g} \mathrm{MS}$ ) corresponding to leaves and bulbs, respectively. The white variety is characterized by (18 and $34 \mathrm{mg} \mathrm{EQ/g} \mathrm{MS)}$ (Table 2) (Figure 4). 
Table 2: ANOVA with two controlled factors: flavonoides (FLAV) as a function of variety (VAR); EXTRACT

\begin{tabular}{|l|l|l|l|l|l|}
\hline \multicolumn{6}{|c|}{ Analysis of variance for Flavonoides } \\
\hline Source & DL & SC & CM & F & $p$ \\
\hline VAR & 3 & 1447.6 & 482.5 & 13.04 & 0.032 \\
EXTRACT & 1 & 792.4 & 792.4 & 21.42 & 0.019 \\
Erreur & 3 & 111.0 & 37.0 & & \\
\hline Total & 7 & 2351.0 & & & \\
\hline
\end{tabular}

For anthocyanins and according to the two-factor variance analysis (Table 3), a complete absence of anthocyanins was found for the white variety, however, the red variety is rich in anthocyanins which is different from one extract to another (Figure 5), the highest content is recorded in the acetone extract.

Table 3: ANOVA with two controlled factors: anthocyanin (ANTH) according to variety (VAR); EXTRACT

\begin{tabular}{|l|l|l|l|l|l|}
\hline \multicolumn{7}{|c|}{ Analysis of variance for ANTH } \\
\hline Source & DL & SC & CM & F & $p$ \\
\hline VAR & 3 & 1.5805 & 0.5268 & 28.15 & 0.011 \\
EXTRACT & 1 & 0.0481 & 0.0481 & 2.57 & 0.0207 \\
Erreur & 3 & 0.0562 & 0.0187 & & \\
\hline Total & 7 & 1.6848 & & & \\
\hline
\end{tabular}

The difference between our results and those found by other researchers is explained by the climatic factor that differs from year to year, the geographical origin and even the handling conditions.

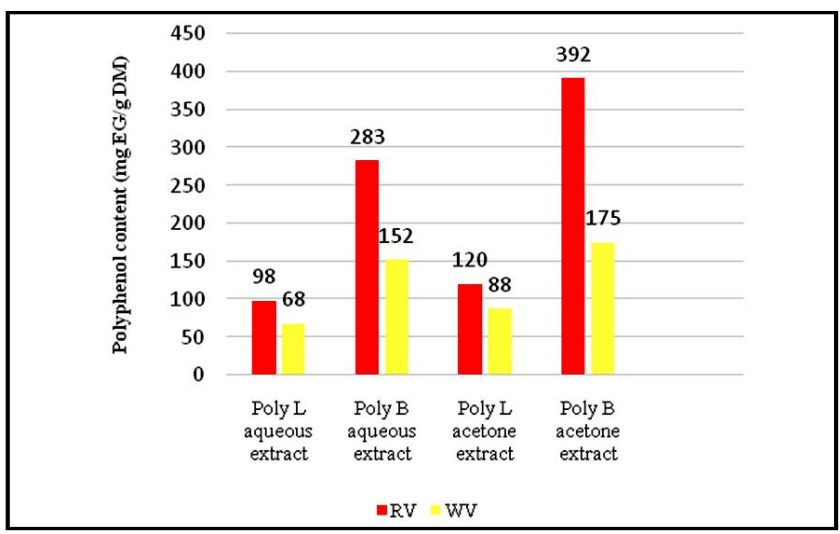

Figure 3: Polyphenol content (mg EG/g DM) in red variety (RV) and white (WV) variety at leaf level (L) and bulb (B).

According to the two-factor statistical analysis (ANOVA), a significant difference was found between the aqueous and acetone extract with the highest value for the latter with respect to the content of three tested compounds (polyphenols, flavonoids, anthocyanins) (Figures 3,4,5).

\subsection{Antidiabetic effect of aqueous extract (EA) in normal and} diabetic mice

\subsubsection{Short-term effect}

The effect of the aqueous extract of $D$. maritima for both varieties at different doses $(0.2,0.4,0.6$ and $0.8 \mathrm{mg} / \mathrm{kg} \mathrm{bw})$ administered orally on fasting plasma glucose in normal mice is shown in (Figure 6).

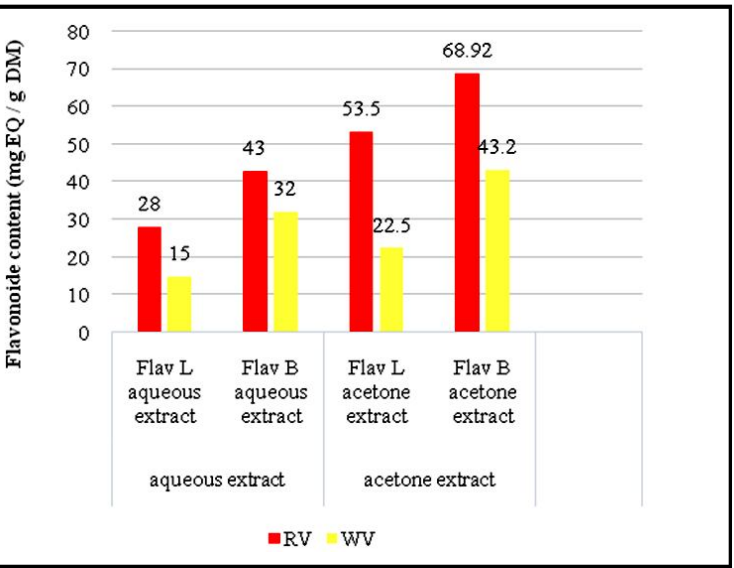

Figure 4: Flavonoid content (equivalent $\mathrm{mg}$ of quercitin/g of dry matter) in red variety (RV) and white variety at leaf level (L) and bulb (B).

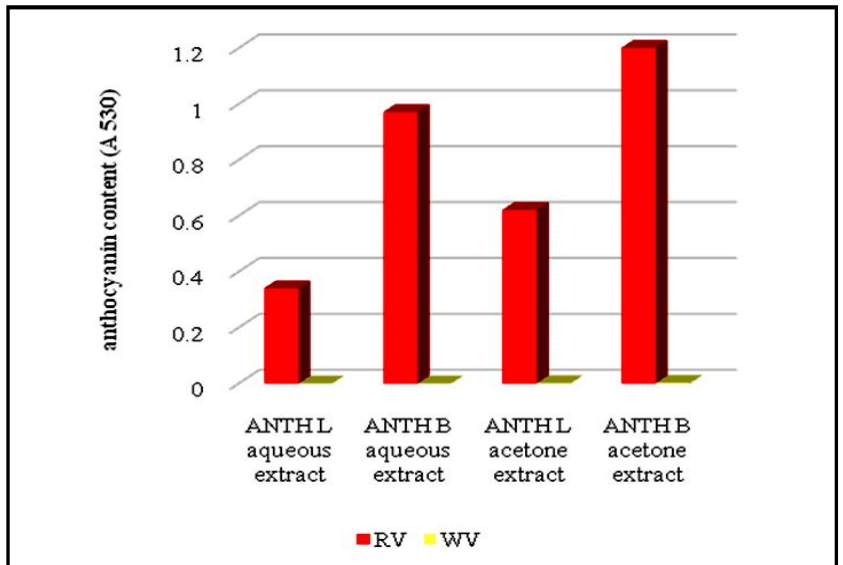

Figure 5: The anthocyanin content (A530) in the red variety, and the white variety at leaf level (L) and bulb (B) acetone extract.

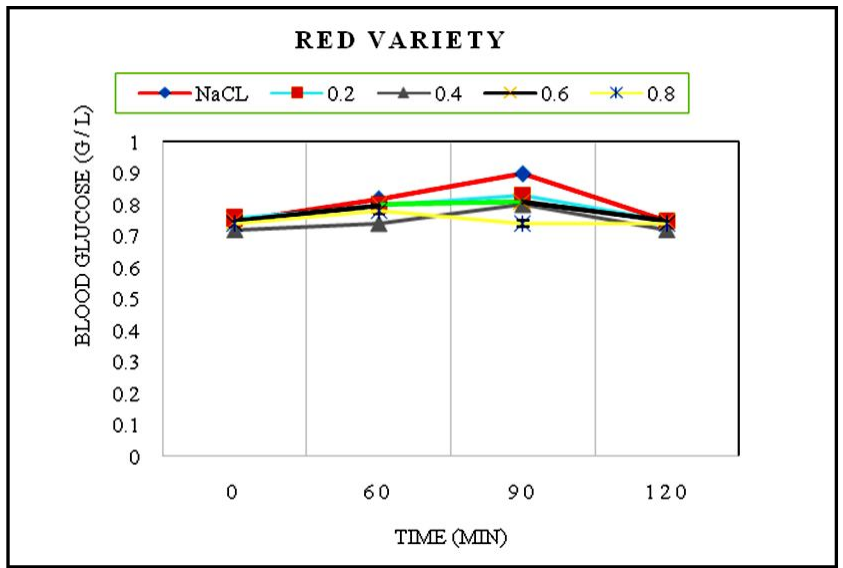

Figure 6: Changes in blood glucose levels in normal mouse treated with the aqueous extract (EA) of D. maritima (red variety) at different doses.

The study of the different curves (Figure 6), which represent the variation in fasting blood glucose over time, shows that there is a significant decrease in blood glucose in our mice treated, with the 
EA extract of the red variety for the $0.8 \mathrm{mg} / \mathrm{g}$ dose, and no effect for the other doses, for the white variety no dose affects blood glucose in normal mice.

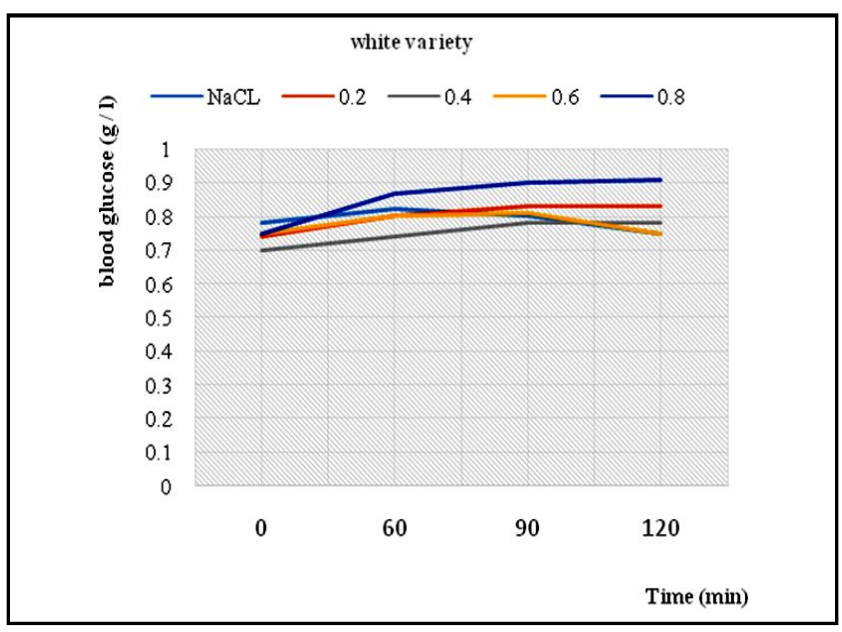

Figure 7: Changes in blood glucose levels in normal mouse treated with the aqueous extract (EA) of D. maritima (white variety) at different doses.

\subsubsection{Effect following an oral glucose tolerance test}

The results of the effect of EA of the red shrimp variety, at doses of 0.2 and $0.8 \mathrm{mg} / \mathrm{kg}$, on blood glucose in normal mice subjected to an oral glucose tolerance test (Figure 8), showed that blood glucose as a function of time, following administration of a glucose solution to mice previously treated with EA extract $(0.2 \mathrm{mg} / \mathrm{kg})$, follows the same profile as that of mice treated with $\mathrm{NaCl}(0.9 \%, 10 \mathrm{ml} / \mathrm{kg})$, but the dose $(0.8 \mathrm{mg} / \mathrm{g}$ b.w. shows a statistically significant decrease in blood glucose levels $30 \mathrm{~min}$ after feeding $(p<0.05)$, compared to other doses, followed by a gradual decrease, which attempts to reach its initial level at $150 \mathrm{~min}$.

For the white rift variety, both doses tested reacted as $\mathrm{NaCl}$, so no significant difference was observed (Figure 7).

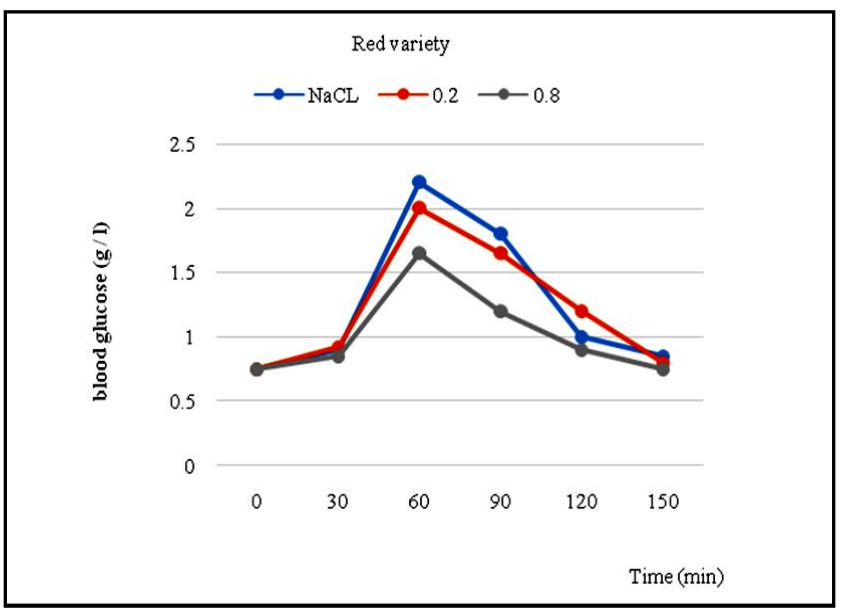

Figure 8: Variations in blood glucose levels in normal mouse treated with D. maritima in aqueous extract (EA) and tested for oral glucose tolerance.

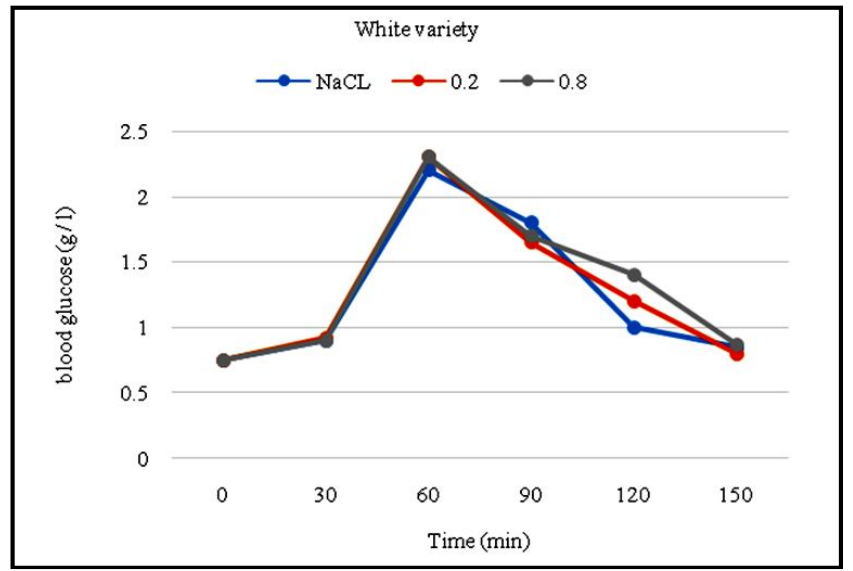

Figure 9: Variations in blood glucose levels in normal mouse treated with D. maritima in aqueous extract (EA) and tested for oral glucose tolerance.

\subsubsection{Long-term effect (7 days)}

A batch of mice made diabetic by alloxane $(60 \mathrm{mg} / \mathrm{kg} \mathrm{bw})$, was orally gave by the aquatic extract at a dose of $0.8 \mathrm{mg} / \mathrm{kg}$ bw, per day, for 7 days, and the effect on hyperglycemia was monitored. The results obtained are shown in (Figure 10).

On the first day of treatment, the fasting blood glucose level of the diabetics in the experimental batch was $2.85 \mathrm{~g} / 1$, and then it became 2.7 on day 7. Similarly, in the mice in the control batch, blood glucose levels were $2.97 \mathrm{~g} / 1$ on day 1 and 2.85 on day 7 . This result shows no significant difference between the experimental and control groups, which means that the EA extract is ineffective for hyperglycemia in diabetic mice.

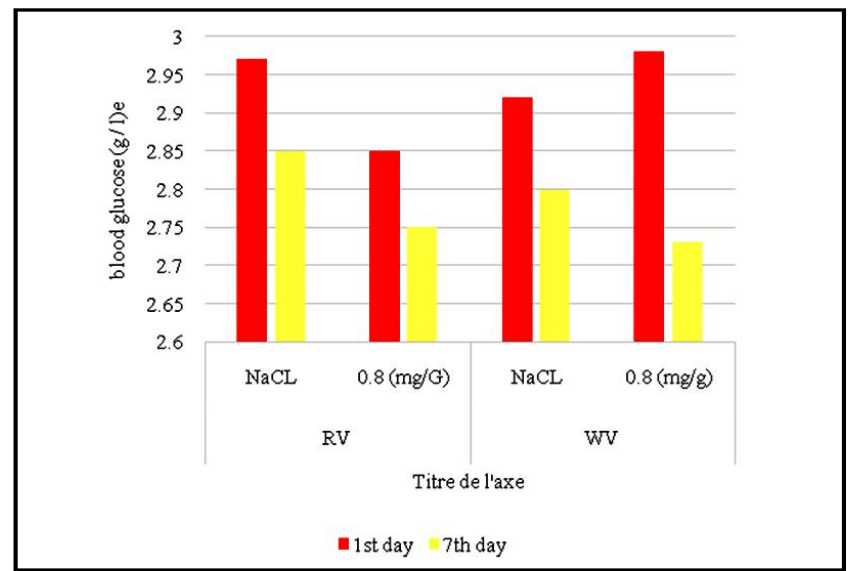

Figure 10: Variations in blood glucose levels in diabetic mouse treated with D. maritima aqueous extract (EA) for 7 days.

3.2.4 Antidiabetic effect of long-term acetone extract (28 days) in normal and diabetic mice

The acetone extract was administered to normal and diabetic mice by alloxan $(60 \mathrm{mg} / \mathrm{kg} \mathrm{bw})$ at a daily dose of $0.8 \mathrm{mg} / \mathrm{kg}$ bw for 28 days. Thus, the results obtained from their effects on fasting blood glucose are shown in Figure 11. In normal mice treated with acetone extract and control mice treated with tween $80(0.8 \%)$, fasting 
blood glucose levels were stable during the 28 days of treatment, whereas a significant difference was observed for the use of acetone extract $(0.8 \mathrm{mg} / \mathrm{g})$ of the red scrape variety in diabetic mice compared to tween. Blood sugar has decreased from $2.98 \mathrm{~g} / 1$ to $1.8 \mathrm{~g} / 1$ after the last week, this result is very important with regard to the use of acetone extracts of the red variety as an antidiabetic treatment.

In contrast to the red squill variety, the white variety behaves similarly to tween, so there is no significant effect of this extract on lowering blood sugar levels in diabetic mice (Figure 12).

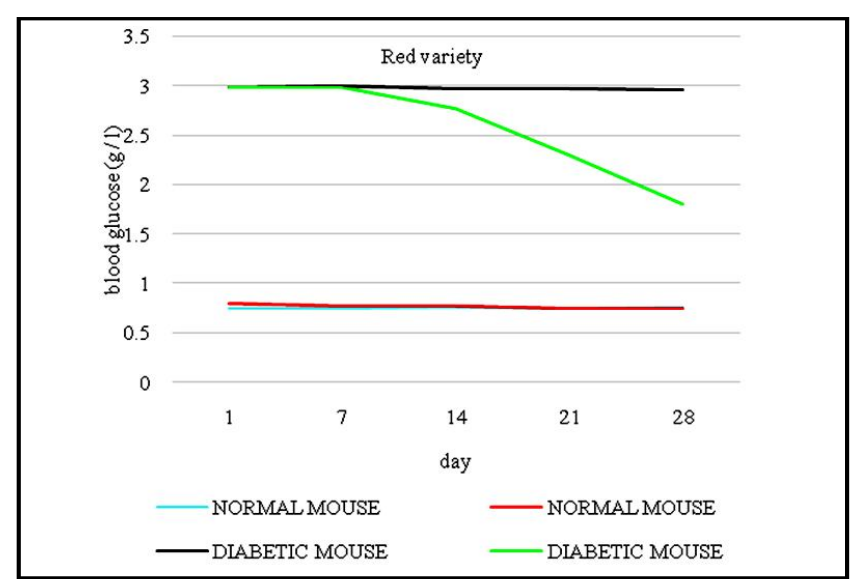

Figure 11: Variations in blood glucose levels in normal mouse and diabetics treated with acetone extract from red variety.

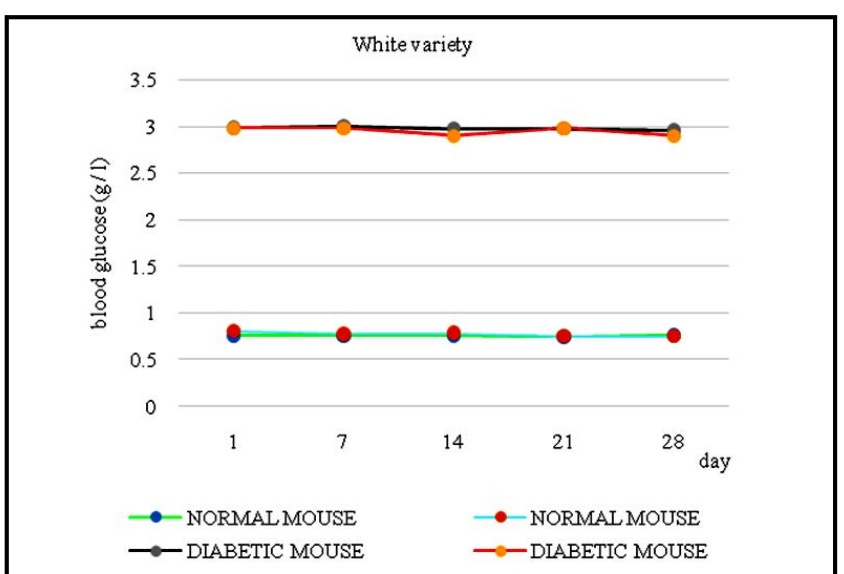

Figure 12: Variations in blood glucose levels in normal mouse and diabetics treated with acetone extract from White variety.

\section{Discussion}

For the squill Maritime, the presence of phenolic compounds, flavonoids and tannins is confirmed by the phytochemical and pharmacological study of the squill Maritime carried out by (Singh, 2016) as well as that of Belhadadad (Belhaddade et al., 2017) which show that the Maritime squill consists of different phenolic compounds, flavonoids and tannins with varying concentrations as well as other biochemical components specific to the Maritim squill

The dominance of polyphenols for both varieties of $D$. maritima is confirmed by the study of Piluzza (Piluzza et al., 2014) which indicates an omnipresence of polyphenols by comparing with the concentration of tannins and flavonoids in the Maritime squill and also the study made by Knittel (Knittel et al., 2014) and which shows a dominance of phenolic compounds in the extract of $D$. maritima over other compounds.

Other study (Wojdylo et al., 2007) determined the concentration of flavonoids in two ethanol extracts $70 \%$ and $80 \%(\mathrm{v} / \mathrm{v})$. This content was estimated at 7.46 and $5 \mathrm{mg} \mathrm{EQ/g}$ Ps in the two extracts, respectively. However, (Akrout et al., 2011) estimated this value at $56.31 \mathrm{mg} \mathrm{ER} / \mathrm{g}$ extract when extracted with a $50 \%$ alcoholic solution. While Saoudi (Saoudi, 2010) found a content of 131.89 $\mathrm{mg} \mathrm{EQ} / \mathrm{g}$ aqueous leaf extract.

The antidiabetic activity of squill was evaluated in vivo in normal Wistar mice made diabetic by alloxan, different extracts were tested, and three procedures were followed. The first procedure is to test the effect of the plant on fasting blood glucose in normal mice. After a $16 \mathrm{~h}$ fast, the animal is in a post-absorptive state, any extract or molecule likely to lower blood sugar levels under these conditions must act by inhibiting hepatic and renal glucose production either directly or indirectly through the release of insulin (Saoudi, 2010). The second procedure tests the effect of the plant on hyperglycemia in normal mice followed oral glucose loading; thus any extract or molecule capable of reducing hyperglycemia can be used to inhibit intestinal glucose absorption, promote glucose utilization by muscle and fat tissue, or stimulate insulin secretion by the pancreas (Saoudi, 2010). While the third procedure tests the effect of the plant, following daily administration of extracts, normal mice and mice made diabetic by alloxan.

In diabetic mice, the significant absence of insulin creates permanent hyperglycemia, in this case any antidiabetic molecule, must mimic the effect of insulin, acting by increasing glucose absorption in muscle and fat tissue, and by inhibiting liver glucose production and the release of free fatty acids (Saoudi, 2010). Experimental diabetes, is created in mice by alloxan.

For our work, we found that the acetone extracts of the red scull varieties have a more effective effect compared to the white variety of the same species, so this effectiveness is explained by the higher content of polyphenols and anthocyanins in the red variety. Many studies have shown that oxidative stress induced by high blood sugar levels generates free radicals and contributes strongly to the development and progression of diabetes and its complications (Ceriello, 2003). Thus, abnormally high levels of free radicals cause cell membrane alterations due to peroxidation of membrane lipids and protein glycation. At the same time, the decline in the body's antioxidant defense mechanisms leads to cell and tissue damage(Ceriello, 2003).

The antioxidant activity of polyphenols, particularly flavonoids, generally depends on their chemical structures, number of hydroxyl groups and their distribution (Popovici et al., 2010; Ceriello, 2003). According to Turkmen (Turkmen et al., 2007), polyphenols appear to be effective donors of hydrogen to the DPPH radical, due to their ideal chemical structures (Ouali and Lafifi, 2018).

\section{Conclusion}

Diabetes is an old disease whose classic symptoms: severe hunger and thirst with increased urine volume, thinness or obesity, risk of coma, are well known by the majority of healers or traditional practitioners; many plants are traditionally considered as antidiabetic some are at the origin of the development of drugs, e.g.: biguanide metformin thanks to Gallega officinalis. 
The combination of 2 or 3 plants seems desirable, some act on the release of insulin others at the peripheral cellular level, as a free radical scavenger, on lipid metabolism, hypertension. That said, herbal remedies may in some cases (prediabetes, moderate diabetes) be the only treatment (diet-related) and in other cases (still type 2 diabetes) may contribute to lowering the dosage of antidiabetic drugs while combating the complications of this "disease".

\section{Acknowledgements}

I thank the scientific research team "valorization of the bioresources" under my presidency at the laboratory level of research" genetics, biotechnology and valorization of the bioresources "of the university Mohamed Khider Biskra Algeria

\section{Conflict of interest}

The author declares that there are no conflicts of interest in the course of conducting the research. She had final decision regarding the manuscript and decision to submit the findings for publication.

\section{References}

Akrout, A.; Gonzalez, LA.; El Jani, H.; Madrid, PC. (2011). Antioxidant and antitumor activities of Artemisia campestris and Thymelaea hirsuta from southern Tunisia. Food and Chemical Toxicology. Food and Chemical Toxicology, 49(2):342-347.

Belhaddad, O. E.; Charef, N.; Amamra, S.; Zerargui, F.; Baghiani, A., Khennouf, S.; and Arrar, L. (2017). Chromatographic fractionation, antioxidant and antibacterial activities of Urginea maritima methanolic extract. Pakistan Journal of Pharmaceutical Sciences, 30(1):127-134.

Ceriello, A. (2003). New insights on oxidative stress and diabetic complications may lead to a "causal" antioxidant therapy. Diabetes care, 26(5):1589-1596.

Debussche, X. and Balcou-Debussche, M. (2018). Analysis of health literacy profiles in people with type 2 diabetes: ERMIES-Ethnosocio Research. Public Health, 1(HS1):145-156.

El Fennouni, M. (2012). Plants deemed abortive in traditional abortion practices in Morocco. http://hdl.handle.net/123456789/14540.

Eryilmaz, F. (2006). The relationships between salt stress and anthocyanin content in higher plants. Biotechnology and Biotechnological Equipment, 20(1):47-52.

Festing, M. and Maletzky, M. (2011). Cross-cultural leadership adjustmentA multilevel framework based on the theory of structuration. Human Resource Management Review. Human Resource Management Review, 22(3):186-200.
Hammiche, V.; Merad, R.; and Azzouz, M. (2013). Toxic plants for medicinal use around the Mediterranean. Springer Paris, pp:29-37.

Heshmati, J.; and Namazi, N. (2015). Effects of black seed (Nigella sativa L.) on metabolic parameters in diabetes mellitus: A systematic review. Complementary Therapies in Medicine, 23(2):275-282.

Joly, D.; Brossard, T.; Cardot, H.; Cavailhes, J.; Hilal, M.; and Wavresky, P. (2010). The types of climates in France, a spatial construction. Cybergeo: European Journal of Geography, pp:501-556.

Knittel, P.; Higgins, M. J.; and Kranz, C. (2014). Nanoscopic polypyrrole AFM-SECM probes enabling force measurements under potential control. Nanoscale, 6(4):2255-2260.

Ozel, A.; Demirbilek, T.; and Güler, Y. (2002). Effect of different sowing dates on yield and some agronomic characters of black cumin species under Harran plain arid conditions. Harran Journal of Agricultural and Food Science, 6(3-4):81-84.

Piluzza, G.; Sulas, L.; and Bullitta, S. (2014). Tannins in forage plants and their role in animal husbandry and environmental sustainability: a review. Grass and Forage Science, 69(1):32-48.

Popovici, C.; Saykova, I.; and Tylkowski, B. (2010). Evaluation of the antioxidant activity of phenolic compounds by the reactivity with the free radical DPPH. AUF-University Agency of La Francophonie.

Ribereau-Gayon, P. (1971). The phenolic acids and catechins of grapes and wine. OENO One. International Journal of Grape and Wine Sciences, 6(2):1-7.

Rowsell, H. C. (1986). Regulation of animal experimentation: Canada's program of voluntary control. Acta. Physiologica Scandinavica, 554:95-105

Saoudi, L. (2010). Filemanagement of human hard core in SME for a successful transmission/recovery. Thesis for obtaining the Doctorate New Regime in Management Sciences.

Schlienger, J. L. (2014). Diabetes and herbal medicine: The facts. Metabolic Disease Medicine, 8(1):101-106.

Singh, V. (2016). Physicochemical parameters study of chitosan-starchglutaric acid in acetic acid-water mixtures. Green Chemistry and Technology Letters, 2(4):180.

Turkmen, N.;Velioglu, Y.; Sari, F., and Polat, G. (2007). Effect of extraction conditions on measured total polyphenol contents and antioxidant and antibacterial activities of black tea. Molecules, 12(3):484-496.

Wojdylo, A.; Oszmialski, J.; and Czemerys, R. (2007). Antioxidant activity and phenolic compounds in 32 selected herbs. Food chemistry, 105(3):940-949. maritima L. Ann. Phytomed., 8(2):134-140. 
